\title{
8
}

\section{AUSTRALIAN HIGHER COMMAND IN THE KOREAN WAR The experience of Brigadier John Wilton}

\author{
David Horner
}

Australian higher command in the Korean War is not just a matter of esoteric interest. Rather, from the time of the First World War, higher command arrangements have been a crucial element during most of Australia's military commitments. They have been both a means by which the Australian Government has exercised its sovereignty and an expression of the degree to which Australia has been able to have that sovereignty recognised. The command arrangements in the Korean War have had ramifications that continue to the present. This chapter discusses those higher command arrangements, then focuses on Brigadier John Wilton's command of the 28th British Commonwealth Brigade.

The classic starting point in any discussion of this subject is the First World War. Major General William Bridges, General Officer Commanding (GOC) of the 1st Australian Division as well as commander of the Australian Imperial Force (AIF), was responsible to the Australian Government for the administration of the Australian army forces overseas. But his force came under British command for operations, and the Australian Government had so little control over its deployment that 
it first learned that the Australians had landed on Gallipoli after the event. When Bridges was mortally wounded in May 1915, the GOC of the Anzac Corps, Lieutenant General Sir William Birdwood, a British officer, took command of the AIF, retaining the appointment until the end of the war. By that time the five Australian divisions on the Western Front had been grouped into the Australian Corps, under Lieutenant General Sir John Monash, but he still remained under a British Army commander for operations.

Learning from this experience, early in the Second World War the Australian Government appointed Lieutenant General Sir Thomas Blamey as Commander of the Second AIF, with a charter that made him responsible to the Australian Government for the administration of his force. He was also given authority to challenge orders from the British Commander under whom his force was placed, and to appeal to the Australian Government if he thought his force was being risked unnecessarily. ${ }^{1}$ It was a declaration that Australia was an independent nation whose forces remained under its command even when operating under a British commander.

The situation became more complicated after Japan entered the war and the American General Douglas MacArthur was appointed Commanderin-Chief of the South-West Pacific Area, which included all Australian forces in and around Australia. By this time Blamey was back in Australia as Commander-in-Chief of the Australian Army, but his advice to the government could be overridden if the government accepted contrary advice from MacArthur, as at times happened. Nonetheless, Australian Army officers commanded at army and corps level in the field.

Higher command in the Royal Australian Air Force (RAAF) in the Second World War was less satisfactory. Nineteen RAAF squadrons served in Europe and the Middle East under British command, but few Australian officers commanded at higher than squadron level. In the South-West Pacific the RAAF, like the army, came under MacArthur's command. Similarly Royal Australian Navy (RAN) ships operated under British command in the first part of the war and later operated under American command.

1 Blamey's charter said that, with regard to the employment of the AIF in an emergency, he might 'take a decision on such a question, informing the Commonwealth Government that he is doing so' (quoted in D. Horner, Blamey: The Commander-in-Chief, Allen \& Unwin, Sydney, 1998, pp. 136-7). 
Australia learned several lessons from the experience of the two world wars. First, and ideally, the Australian Government needed to have some say in the process of developing imperial or allied grand strategy. In practice this proved extremely difficult. Second, Australian higher commanders needed to be able to influence the plans of the allied theatre commanders. This too proved difficult, unless Australia provided a large proportion of the forces in the relevant theatre. Australia could, however, influence the theatre commander's plans by the simple, if controversial, practice of denying forces to him—as Blamey did when he denied MacArthur's request to use the 6th Division for the invasion of Java. ${ }^{2}$ The third lesson was the need to aggregate Australian forces into large groups under an Australian commander, thereby giving that commander more influence and also more experience of higher-level command.

These higher command problems were not surprising, given that Australia was a small country operating in a larger allied coalition. Bigpower jealousies were difficult to overcome. In the South-West Pacific, the United States was loath to place its army formations under Blamey, as Commander, Allied Land Forces, even though his appointment was difficult to challenge, given that Australia provided 12 and the United States only two of the 14 infantry divisions in that theatre.

Similarly, Britain was reluctant to cede to Australian military leadership, even when the Australians were in superior numbers. Nonetheless, after the war Australia insisted on providing the Commander-in-Chief of the British Commonwealth Occupation Force (BCOF) in Japan. BCOF included a British-Indian division of two brigades, an Australian brigade, a New Zealand brigade and considerable numbers of Australian administrative troops. The Commander-in-Chief of BCOF came under American operational control (the Americans being in charge in Japan), but for policy and administrative matters he reported to the Australian chiefs of staff, who were supplemented by representatives from the other Commonwealth countries involved. The decision to appoint an Australian officer as Commander-in-Chief of BCOF was to have significant ramifications for higher command in the Korean War.

Unlike the situation in the South-West Pacific in 1942-43, when Australia provided the majority of General MacArthur's ground troops, Australia's military commitment to Korea was relatively modest. We might note in

2 Ibid., pp. 502, 516-17. 
passing that in 1950 the Australians in Korea were still serving under MacArthur's command, as he was Commander-in-Chief of the United Nations Command.

Except for the 28th Brigade, to be discussed shortly, Australia's military commitment to Korea was generally at unit level. As noted earlier, soon after the outbreak of the war, the Australian destroyer HMAS Bataan and the frigate HMAS Shoalhaven, then serving in Japanese waters, joined a British naval task group operating off the coast of Korea. Australia attempted to maintain two ships on station for the remainder of the war; a total of nine RAN vessels served there, some returning for a second tour. As noted by Jack McCaffrie in Chapter 7, the aircraft carrier HMAS Sydney also served in Korean waters from October 1951 to February 1952. In each case the RAN ships operated as part of British task groups. Sometimes, when an Australian destroyer was commanded by a senior captain, he commanded a task group of Allied ships, thereby gaining valuable higher command experience, albeit at the tactical level. ${ }^{3}$

As mentioned by Richard Hallion in Chapter 6, Mustangs from the RAAF's No. 77 Squadron began operations over South Korea in 1950; the squadron served in Korea until the end of the war, generally operating as part of a US Air Force wing. No Australian air force officer was able to command at higher than squadron level.

The 3rd Battalion, Royal Australian Regiment (3RAR), arrived in Korea in September 1950 and joined the 27th British Brigade, which thereby became the 27th British Commonwealth Brigade. As part of the brigade, 3RAR took part in the advance into North Korea in late 1950, the subsequent withdrawal, the gallant defensive battle at Kapyong in April 1951, then, as part of the 28th Brigade, in the brilliant attack on Maryang San in October 1951. The battalion remained part of the 27th Brigade until April 1951, when the 28th British Commonwealth Brigade was formed. In June 1952, the 1st Battalion, Royal Australian Regiment (1RAR), joined 3RAR in the 28th Brigade, which, with two British battalions, had four infantry battalions. An Australian brigadier, Thomas Daly, took command of the brigade. In turn, Daly was succeeded by Brigadier John Wilton, whose experiences will be described later.

3 R. O'Neill, Australia in the Korean War 1950-53, vol. 2: Combat Operations, AWM \& AGPS, Canberra, 1985, p. 528. 
Therefore, until Daly took over, successive commanders of 3RAR were the highest ranked Australian Army operational commanders in Korea. One should not discount the additional responsibility borne by an Australian battalion commander operating in an allied army in a period of intense fighting. Major General David Butler, who served as a platoon commander in 3RAR in 1950 and later commanded an infantry battalion in South Vietnam, has commented that Lieutenant Colonel Charles Green, who commanded 3RAR in 1950, had a period of command 'without parallel in the history of the Australian Army':

No-one has been invited to put together a unit in such a short time and take it into action so quickly. The actions he fought were in a sense quite solitary and not only because he was commanding a lone Australian battalion. No Australian CO in either world war experienced encounter battles of the kind Green faced. ${ }^{4}$

After Green was killed, Lieutenant Colonel Bruce Ferguson commanded the battalion in the bitterly cold withdrawal and in the Battle of Kapyong in April 1951. According to Ferguson's intelligence officer, Alf Argent, a contributing factor in Ferguson's relief as commanding officer in June 1951 was his reluctance to replace officers and men with reinforcements from Japan at a time when, in his view, such replacements would have gravely affected his battalion's fighting efficiency. ${ }^{5}$ Further, when there was a dispute over giving leave to soldiers, Ferguson could not explain to the headquarters in Japan how short of men he was on the ground. As Butler put it: 'Unfortunately it was a national matter, which his British brigade commander could not take up on his behalf.' ${ }^{\prime}$ So while Green, Ferguson and his successor, Frank Hassett, were tactical unit commanders, they had the additional burden of national responsibilities.

On the other side of the equation, the British commander of the 27th Brigade ordered 3RAR to withdraw after its successful defence of Kapyong because he was 'aware that he was responsible to the Australian Government for the safety of its battalion, and that searching questions would be asked if the only Australian ground force in Korea was wiped out'. ${ }^{7}$ It seems that the Australian battalion commanders were never given

4 D. Butler, A. Argent and J.J. Shelton, The Fight Leaders: A Study of Australian Battlefield Leadership, Australian Military History Publications, Loftus, NSW, 2002, p. 70.

5 Ibid., p. 111.

6 Ibid., p. 149.

7 J. Grey, The Commonwealth Armies and the Korean War: An Alliance Study, Manchester University Press, Manchester, 1988, p. 85. 
any directives that would allow them to appeal against orders in which their troops might be placed at risk, perhaps because the Australian chiefs of staff believed that, as will be explained shortly, the Commander-inChief British Commonwealth Forces Korea, an Australian general, would keep watch on such problems. ${ }^{8}$

So to an extent the Australian battalion commanders were not completely without moral support, and they had another avenue of support as well. At the outbreak of the Korean War, 3RAR, No. 77 Squadron, RAAF, and Australian administrative units were serving as part of BCOF in Japan. By this stage the British, Indian and New Zealand elements of BCOF had left Japan, and Australia was preparing to withdraw its forces as well. The Commander-in-Chief of BCOF, the Australian Lieutenant General Sir Horace Robertson, who had been there since 1946, was still in command. When 3RAR and No. 77 Squadron were deployed to Korea, BCOF provided a convenient administrative base in nearby Japan. Further, when the 27th British Brigade went to Korea, and 3RAR became part of it, the Australian, British, Canadian and New Zealand governments agreed that Robertson would take up the appointment of Commander-in-Chief British Commonwealth Forces Korea. Robertson had the command infrastructure that could be readily adapted to provide administrative support for the Commonwealth forces deployed to Korea.

The 27th Brigade was under the operational control of an American division, with ultimate operational control stretching back to MacArthur in Tokyo. But according to his directive, Robertson was required to maintain the forces in Korea and Japan and to interest himself in the operational tasks allotted to the United Kingdom, Australian, New Zealand and Canadian Forces'. ${ }^{9}$ He was to maintain close contact with the Commonwealth commanders in Korea and to represent their cases to MacArthur. Robertson was also to report to the Australian Chiefs of Staff Committee, which for the purpose was augmented by representatives from the other Commonwealth countries.

The British Commonwealth base at Kure in Japan was commanded by an Australian, Brigadier Ian Campbell, who was also commander of the Australian Component of the British Commonwealth Forces Korea. Robertson took a keen interest in the operations of all the Commonwealth 
forces in Korea. It was he who appointed Walsh to command 3RAR when Green was killed in November, and he accepted the decision of the British brigade commander to dismiss Walsh from his command and to appoint Ferguson just over a week later. ${ }^{10}$ According to Major General Ron Hopkins, Robertson was present in Korea when part of the British 29th Infantry Brigade was overrun by superior Chinese forces in April 1951; Robertson insisted, without success, that he visit the forward British battalions. He returned to Japan 'and peremptorily ordered his staff to round up all available reinforcements in Japan'. By noon the next day reinforcements were arriving to strengthen the 29th Brigade. ${ }^{11}$

In October 1951, another Australian officer, Lieutenant General William Bridgeford, succeeded Robertson as Commander-in-Chief British Commonwealth Forces Korea. In February 1953, Lieutenant General Henry Wells succeeded Bridgeford. After this appointment, Wells became Chief of the General Staff, then, at the end of that appointment, in 1958 he became Australia's first separate Chairman of the Chiefs of Staff Committee. While the successive Commanders-in-Chief held a significant appointment, their ability to influence high-level decision-making was undermined by the fact that Britain appointed a senior officer, Air Vice Marshal Cecil Bouchier, as liaison officer at MacArthur's headquarters in Tokyo.

Although the position of Commander-in-Chief British Commonwealth Forces Korea sounded grand, the most important operational position was that of the Commander of the 1st Commonwealth Division. This division was formed in July 1951, bringing together the 28th Commonwealth Brigade (which included 3RAR), the British 29th Brigade and the Canadian 25th Brigade, along with support troops, including some from India and New Zealand. The commander of the division was a British officer, Major General James Cassels.

There is plentiful evidence of Cassels's disputes with his American corps commander, Lieutenant General John ('Iron Mike') O’Daniel, over his belief that at times he was asked to undertake operations that would unnecessarily cause casualties. As Cassels wrote in October 1951, his main trouble was convincing O'Daniel that, 'although we were more

10 O’Neill, Combat Operations, pp. 60, 64.

11 R. Hopkins, 'Lieutenant-General Sir Horace Robertson: Commander-in-Chief British Commonwealth Occupation Force', in The Commanders: Australian Military Leadership in the Twentieth Century, ed. D.M. Horner, George Allen \& Unwin, Sydney, 1984, p. 295. 
than ready to do anything that was required, we did like to know the reason behind it. On many occasions I was ordered without warning to do things which I considered militarily unsound and for which there was no apparent reason'. ${ }^{12}$ Cassels was a first-rate officer. He had commanded a brigade in Normandy during the Second World War and a division in Palestine on counter-insurgency operations in the late 1940s. Later, with the rank of field marshal, he was British Chief of the General Staff. Unlike the American division commanders, he was prepared to argue with his corps commander in Korea and, as the historian Jeffrey Grey has written, he 'managed to talk O'Daniel out of most of his wilder flights of fancy'. ${ }^{13}$

This rather long introduction provides a necessary background to the discussion of Brigadier John Wilton's role as commander of the 28th Brigade.

It has sometimes been thought that Wilton was a consummate staff officer and that his posting in Korea was designed to give him command experience before he went on to higher rank in the Australian Army. By contrast, it might be noted that his predecessor in command of the 28th Brigade, Tom Daly, had commanded the 2/10th Infantry Battalion in the landing at Balikpapan in Borneo in 1945. In fact the opposite was the case. In the first 10 years of his military service, Wilton spent more time in command appointments than any of his Australian Army contemporaries.

Partly this came about because, after graduating from Duntroon in 1930, he joined the British Army, no position being available in the Australian Army. After his initial artillery training in Britain, in June 1931 he joined an artillery regiment that five months later embarked for India. In February 1935 he transferred to a mountain battery and served, with a small amount of action, in Burma. By early 1939 he was serving in a coastal battery at Karachi, and when he returned to the Australian Army in mid-1939 he went to the Australian Army's largest permanent unit, the 1 st Heavy Brigade in Sydney, and was soon commanding a coastal battery.

When Wilton joined the Second AIF in May 1940, he was given command of a field battery, which he led in Palestine and Egypt until February 1941. He then became brigade major of the 7 th Division artillery, serving in that

12 Quoted in Grey, The Commonwealth Armies and the Korean War, p. 138.

13 Ibid., p. 141. 
role in the Syrian campaign. Wilton had an almost unbroken period in command, admittedly much of it at a junior level: just short of 10 years. Wilton was General Staff Officer Grade One (GS01) of the 3rd Division during the Salamaua campaign in New Guinea in 1943, and when the headquarters of the 5th Division took over the campaign, its GSO1 was none other than Thomas Daly. When Daly was commanding the $2 / 10$ th Battalion at Balikpapan, Wilton was on the operations staff of General Blamey's advanced headquarters at Morotai. When, after the war, Wilton was Director of Military Operations and Plans at Army Headquarters, Daly was Director of Military Art at Duntroon.

Despite this rather impressive background, when he arrived in Korea in March 1953 to take over from Daly, Wilton was conscious that his British colleagues had even more impressive credentials. Major General Mike West, who had succeeded Cassels as commander of the 1st Commonwealth Division, had commanded a brigade at Kohima in 1944 - the bloodiest battle of the war in Burma. Brigadier Douglas ('Joe') Kendrew, commander of the 29th Brigade, had won three Distinguished Service Orders (DSO) as a battalion and brigade commander in the Second World War. Brigadier Jean Allard, who arrived a little later to take over the 25th Canadian Brigade, had also won three DSOs commanding a battalion and a brigade in the Second World War. Wilton had won only one DSO. Allard would later become Chief of the Defence Staff of the Canadian Forces.

The division had strong artillery support, and the commander of the divisional artillery, Brigadier Guy Gregson, DSO, MC, had Canadian, British and New Zealand field regiments, a British light regiment and a British medium battery. The 16th New Zealand Regiment was in direct support of the 28th Brigade, but in defensive battles the brigade would be able to call upon not only the divisional but also the corps artillery. Wilton was pleasantly surprised to find that the commanding officer of the 20th Field Regiment Royal Artillery was Lieutenant Colonel Geoff Brennan, one of his fellow Duntroon graduates who had transferred to the British Army with him back in 1931.

With two British and two Australian battalions-1st Battalion, Royal Fusiliers (1RF), 1st Battalion, Durham Light Infantry (1DLI), 3RAR and the newly arrived 2RAR-Wilton's brigade was the strongest in the division, and also included units from most countries of the Commonwealth. As mentioned above, its direct support regiment was 
from New Zealand, and the 60th Indian Field Ambulance also supported it. The battalion commanders were capable and experienced infantry officers. Lieutenant Colonels Peter Jeffreys, DSO, OBE (1DLI), and Dick Stevens, OBE (1RF), had commanded brigades of their own in the Second World War. By contrast, the Australian battalion commanders had less command experience, although they were no less able; they had much experience as staff officers on active service. Lieutenant Colonel Arthur MacDonald (3RAR) had served with Wilton at Army Headquarters (AHQ). Wilton observed that MacDonald, who would become Chief of the Defence Force staff in the 1970s, had 'settled down quite well and is fit and full of confidence as ever'. George Larkin, who commanded 2RAR, was 'having quite a job getting his battalion settled down and used to the new conditions. ${ }^{14}$

Wilton formally took command on 25 March 1953, and on 7 April the Commonwealth Division began to move forward to take over from the US 2nd Division in the Jamestown Line. The 28th Brigade occupied the right-hand sector, including Hill 355, the Canadian 25th Brigade was in the centre, and the 29th Brigade was on the left, defending the Hook. Wilton deployed 1DLI on Hill 355 and 1RF on Hill 159, and the two Australian battalions in reserve. The US 2nd Division had taken to heart the injunction to avoid clashes with the enemy. Before long, both of Wilton's forward battalions were in contact, and in a patrol clash on 23 April, 1RF lost one killed, two wounded and one missing. ${ }^{15}$

With no offensives to plan and a generally static defence line, at first glance there seemed little for the higher commanders to do. According to Brigadier Allard:

[A] brigade commander could not, on his own initiative, mount an offensive that would involve more than a platoon. To attack with a company we had to obtain permission from the army corps commander-the divisional commander did not have that power of decision-and the corps commander had to have the blessing of the army commander to involve more than one company. ${ }^{16}$

14 Wilton to Helen, 25 March 1953, Wilton family papers.

15 War diary, 28th Brigade, April 1953, TNA: WO 281/711.

16 J.V. Allard, with S. Bernier, The Memoirs of General Jean V. Allard, University of British Columbia Press, Vancouver, 1988, p. 173. 
As a result, the brigade commander could not test the defensive capability of his opponents or the offensive capability of his own troops. Further, if the enemy dominated his defences, he could not mount an attack to drive him off his forward positions.

The brigade commander's prime duty was to remain ready to deal with a Chinese offensive while maintaining the morale and efficiency of his units. On the night of 14 April, a 1DLI patrol clashed with a Chinese patrol; Wilton took the opportunity to rehearse his battle procedure, communications and counter-attack plans. As he wrote to his wife, he thought that 'all went off very well': 'I'm quite confident now about this job and except on rare occasions when there is a minor "flap" on about a patrol clash etc I shall have a fairly easy time unless the Chinaman decides to carry out a big offensive. ${ }^{17}$

Wilton knew that it was important to keep a close watch on activities in the line and to be seen by the troops. The best time to visit was in the early morning. Most of the troops were awake at night, manning the forward positions and sending patrols into no man's land. So if he was to see the troops, he needed to arrive about an hour before they stood down after the night's work. Further, if he drove up to the front line in his jeep during the day, the enemy would shell him. Hence, two or three times per week he woke at $4 \mathrm{am}$, drove to one of the forward battalions, then sent his jeep back to his headquarters. After completing his morning inspection, he would then walk back through the communication trenches, which, he assured his wife, was 'quite safe but fatiguing..$^{18}$

Wilton's other concern was to establish his reputation. He was conscious that he was the only brigadier in the division who had not commanded a unit in combat. As he confided to his wife, his problem was 'to obtain and maintain the respect of the British COs, both of whom are very experienced infantry officers who in the last war both commanded brigades of their own': 'So you can see that my relations and attitude towards them must be different to that which I can adopt towards MacDonald and Larkin. However, I'm not unduly concerned-it's merely a matter of time and handling them carefully.' ${ }^{19}$ To the divisional commander he was also an unknown quantity, but by 18 April he thought that his relations with

17 Wilton to Helen, 18 April 1953, Wilton family papers. For the patrol clash, see war diary,

28th Brigade, April 1953, TNA: WO 281/711.

18 Wilton to Helen, 12 April 1953, Wilton family papers.

19 Ibid. 
West were good. 'We are getting to know each other better. I naturally feel that he is watching me very closely to make sure that I'm up to the job and that is normal of course. He is very friendly and helpful and ready to give advice.' In the first week of May, Wilton ordered his two Australian battalions to relieve the British battalions in the forward positions. On 14 May a Chinese propaganda broadcast welcomed the Australians to the front line, adding, 'We hope you will preserve the good names of the previous two battalions'. ${ }^{20}$

It was not long before both battalions were in action with fierce patrol clashes in no man's land and ambushes by both sides. The Chinese shelled the forward positions, and one Australian patrol received casualties in one of their own minefields after straying into it while in contact with the enemy. The 29th Brigade, defending the Hook on the left flank of the division, came under sustained attack beginning on 8 May. Shelling increased on 20 May, and a full-scale assault began on 28 May. The 29th Brigade received an estimated 10,000 incoming rounds of artillery, but the divisional artillery replied with 32,000 rounds plus a further 5,000 from the corps artillery and 500 from the Royal Tank Regiment. The 29th Brigade repulsed the Chinese brigade-sized attack, inflicting heavy casualties-estimated by Major General West at 250 killed and 800 wounded. ${ }^{21}$ Wilton confided to his wife that Brigadier Kendrew was a 'good solid chap although I would not say he is a clever chap by any means'; all the same, Kendrew understood how to fight a battle and was awarded another DSO for this action. ${ }^{22}$ Referring to the Chinese artillery attack, Kendrew commented: 'In the whole of the last war I never knew anything like that bombardment. ${ }^{23}$ The 28th Brigade's casualties in May were 20 killed, 116 wounded and seven missing in action, mostly incurred by the Australian battalions.

Wilton's brigade major, Bill Morrow, had served with Brigadier Daly for three months and was in an excellent position to compare the two brigade commanders. He thought that both were 'very fine' commanders. Daly was 'more gregarious' and would talk easily with the soldiers. Wilton was 'very intelligent and very quiet'. Morrow was impressed by Wilton's 'very

20 War diary, 28th Brigade, May 1953, TNA: WO 281/711.

21 Despatch by Major General M.M.A.R. West, p. 10, private papers of General Sir Michael West, GCB, DSO, Imperial War Museum, Documents, 11300.

22 Wilton to Helen, 9 June 1953, Wilton family papers.

23 A.J. Barker, Fortune Favours the Brave: The Battle of the Hook, Korea, 1953, Leo Cooper, London, 1974 , p. 143. 
cool, calm and collected manner' in moments of tension. The Battle of the Hook was a good example. The Chinese artillery had been building up during the latter days of May until the final assault beginning on 28 May. As the night progressed, Morrow awakened Wilton to tell him about the attack. As Morrow recalled, 'he was wonderfully cool'. He replied, 'Well, there is not much we can do at this stage. Keep your eye on it and give me a call when things develop'. ${ }^{24}$

In late May, 1DLI relieved 3RAR, and on 16 June 3RAR relieved 2RAR. The patrol clashes, ambushes and artillery bombardments continued; during the month the brigade suffered 20 killed, 133 wounded and six missing - distributed equally among 1DLI, 2RAR and 3RAR. ${ }^{25}$ Wilton was now well into his stride as a brigade commander, and in a letter to his wife on 21 June he reflected on his responsibilities:

I must say that if this phoney sort of war goes on much longer I am going to get very bored because there is no scope for much initiative for a brigade commander. The battalion commander has the interesting and busy job and my main job is to see that the battalion commanders do theirs properly and to coordinate their activities. ${ }^{26}$

In the second week of July, Major General West reshuffled his brigades. The 28th Brigade moved across to take over the left flank position, including the Hook. The Canadian 25th Brigade relieved the 28th Brigade, and in turn the 29th Brigade occupied the centre position.

Wilton was now responsible for the division's most threatened area. The Chinese had made frequent attacks against the Hook, aware that if they could take this feature they could dominate the Imjin River, 4 kilometres to the south. Wilton deployed 2RAR into the left forward area, on the Hook. 3RAR was on its right, overlooking the Samichon River, 1DLI was on the opposite side of the Samichon, and 1RF was held in reserve to deal with major enemy penetrations of the brigade's defences. The Turkish Brigade had previously held the position to the left of 2RAR, but the 7th Regiment of the US Marines 1st Division had now replaced it.

24 Brigadier W.J. Morrow to author, 21 November 2002.

25 War diary, 28th Brigade, June 1953, TNA: WO 281/711.

26 Wilton to Helen, 21 June 1953, Wilton family papers. 
This was a difficult time for the troops. On 8 June, UN and Chinese negotiators signed an agreement on the exchange of prisoners, and only the final details of the demarcation line remained to be concluded. By mid-July, South Korea had agreed to accept the terms of the armistice and a final truce seemed near. Meanwhile, on the night of 19/20 July the Marines were driven off two positions near 2RAR, exposing its positions further. Patrol clashes indicated that the Chinese were building up for yet another assault. To the troops in their trenches, it seemed futile to risk their lives.

At 6.15 in the evening of 23 July, Wilton called his battalion commanders together to inform them that the signing of the armistice agreement was imminent and that they were to send out only those patrols essential to the security of their positions. The following evening, the Chinese bombardment of the Marines and the left flank of 2RAR grew in intensity. Large bodies of Chinese were seen on the forward slopes of the 2RAR positions, while enemy forces surrounded a 2RAR bunker on the left flank. The Marine liaison officer at brigade headquarters reported that Chinese were probing the Marine positions. Sitting quietly in his command post, at $9.10 \mathrm{pm}$ Wilton ordered one company of 1DLI to occupy a reserve position on the 2RAR left flank, to the rear of the US Marine Division, and the reserve company of 3RAR to be 'embussed and ready to move in event of emergency. ${ }^{27}$ Nineteen-year-old Sergeant Brian Cooper, commanding a section from the 2RAR machine gun platoon on the extreme left flank within the Marine perimeter, called down the Commonwealth Division artillery around his own and the Marines' position to break up the enemy attacks. ${ }^{28}$ One of Cooper's mates well remembers the feeling of being let down as the Marines filed past their position, pulling out: 'Then there was the realisation that when they were gone, there was just us! ${ }^{29}$

Throughout the next day, the Chinese maintained a slow but persistent shelling of the Australian positions, stepping up the intensity in the evening. That night the Marines on the nearby hills came under a fierce assault, necessitating a counter-attack. At $12.45 \mathrm{am}$ Wilton ordered the

27 War diary, 28 Commonwealth Brigade, July 1953, TNA: WO 281/712.

28 B. Cooper, 'Recollections of Korea, July 1953', in Korea Remembered: The RAN, ARA and RAAF in the Korean War of 1950-1953, ed. M. Pears and F. Kirkland, Doctrine Wing, Combined Arms Training and Development Centre, Georges Heights, NSW, 1998.

29 'Ron' Walker, 'Last days on the "Hook"-1953', in Korea Remembered, ed. Pears and Kirkland, p. 163. 
reserve company of 3RAR to move across to occupy the position behind 2RAR, and at 2.18 am he placed one company of 1DLI on five minutes' notice to move to a blocking position. By dawn the Chinese attack had been repulsed, and Wilton went forward to visit 2RAR, 3RAR and 1DLI. During two nights, 2RAR had lost five killed and 24 wounded, while in the same period the Marines had 43 killed and 316 wounded. Over three nights the Commonwealth Division's artillery fired almost 23,000 rounds, and the Marine artillery fired a similar number. By contrast, the 28 th Brigade recorded only 2,700 incoming rounds. ${ }^{30}$

There were no further contacts on the night of 26 July, as news came that the armistice would be signed at $10 \mathrm{am}$ the next day, to come into effect at $10 \mathrm{pm}$. In the morning of 27 July, Wilton boarded a light aircraft to fly to Panmunjom. There, on behalf of Australia, he witnessed the signing of the armistice documents.

At dawn on 28 July, West and Wilton went forward to inspect 2RAR's forward positions. Standing on the bunkers, he studied the Chinese positions. He wrote later:

The floor of the valley between the Hook and the Chinese position was almost covered with dead Chinese who had been caught by our deadly defensive-fire artillery concentrations. On the immediate approaches to 2RAR the bodies literally carpeted the ground sometimes two deep. It was a terrible sight which I will never forget. ${ }^{31}$

We are never likely to know the numbers of Chinese killed in the 2RAR area. Whatever the actual numbers, it was a salutary illustration of the power of concentrated artillery and the wastefulness of massed attacks. As a professional gunner, Wilton later reflected on the fact that in normal circumstances nothing can stand in the way of a 'solidly packed' human wave attack on a front of about 500 to 1,000 metres, except if the defender has access to a large amount of artillery support.

30 War diary, HQ RAA, 1st Commonwealth Division, July 1953, TNA: WO 281/728; P. Meid and J.M. Yingling, US Marine Operations in Korea 1950-1953, vol. V: Operations in West Korea, Historical Division, Headquarters US Marine Corps, Washington, DC, 1972, p. 388. The 1st Commonwealth Division, Periodic Report, 1 April 1953-1 August 1953 (TNA: WO 308/65), claimed that 4,000 rounds fell on the divisional position on 25 July, mainly on the Hook and point 121.

31 Quoted in O’Neill, Combat Operations, p. 282. 
The Australians' last battles at the Hook received little notice in the histories of the war (except for the Australian official history). ${ }^{32}$ During two weeks on the Hook, 2RAR lost 17 killed and 32 wounded. By comparison, in the celebrated Battle of Long Tan in the Vietnam War in August 1966, the Australians lost 18 killed and 24 wounded, inflicting, by Australian records, 245 enemy deaths. ${ }^{33}$ In May 1968 in Vietnam, the Australian task force, with two battalions deployed, fought what the official history describes as 'their largest, most hazardous and most sustained battles of the war'. Australian casualties were 20 killed and 95 wounded. Enemy casualties from the Australian operations numbered more than 200. ${ }^{34}$

Wilton had fought his last battle; but he remained in Korea commanding his brigade until February 1954. He found the time in Korea to be a worthwhile experience. He later reflected:

If I hadn't had that experience in command of operations in the field at that level I wouldn't have been as well equipped as I should be later on when I became a general and, subsequently, head of the Army. You can't have a bloke heading the Army who hasn't commanded anything more than a small unit in the field.

Of course, he was not tested in fast-moving operations. As he later explained, the decision-making was 'not very difficult because you had plenty of time to work out your dispositions and counter-attack plans and fire plans, and it was just a question of which one to put into effect according to where the attack came from'. ${ }^{35}$

He learned much about cooperation with allied armies. He had already had considerable service with the US Army, but the experience in Korea confirmed his critical views about the American approach to war-a view that would colour his thinking when dealing with the Americans in Vietnam 10 years later. Further, he met 'a lot of American and British

32 The British official history deals with the battle in one sentence; see A. Farrar-Hockley, The British Part in the Korean War, vol. 2: An Honourable Discharge (HMSO, London, 1995), p. 383. FarrarHockley (p. 383) also claims that Lieutenant Colonel Jeffreys of 1DRL had planned a counter-attack on 26 July to recover a company area, and that Wilton left it to him to decide whether to do so. This seems unusual as 1DRL was in a reserve position.

33 I. McNeill, To Long Tan: The Australian Army in the Vietnam War 1950-1966, Allen \& Unwin/ AWM, Sydney, 1993, pp. 356, 368.

34 I. McNeil and A. Ekins, On the Offensive: The Australian Army in the Vietnam War, January 1967-June 1968, Allen \& Unwin/AWM, Sydney, 2003, pp. 349, 396.

35 Transcript of interviews conducted by J. Wilton and J. Eisenberg, pp. 79-80, McNeill papers, held by the author. 
officers' whom he was to meet again in the Southeast Asian Treaty Organization (SEATO), Malaysia and Vietnam. ${ }^{36}$ One of these was General Maxwell Taylor, commander of the US Eighth Army, who would become Chief of Staff US Army, special adviser to President Kennedy, Chairman of the US Joint Chiefs of Staff, and later US Ambassador in Vietnam. ${ }^{37}$ Operationally, Wilton particularly noted the value of helicopters; the Commonwealth Division had none, but the US Army made its own available when needed. Years later he would fight for the Australian Army to have its own helicopters.

The problem of maintaining one and later two battalions in Korea was another crucial lesson. Because there was no ready replacement at the time, 3RAR remained in Korea throughout the war, being sustained by a process of individual replacement as soldiers completed their 12 months service. As Wilton wrote later, each unit was in a constant process of change, and no sooner had the subunits and units built themselves up as a team when half the team went away'. ${ }^{38}$ By comparison, 1RAR was completely relieved by 2RAR. In the lead-up to the Vietnam War he would argue for a larger army, and would lay down the policy for the relief of complete units.

Wilton's experience commanding the 28th Brigade therefore taught him much more than the relatively straightforward (but nonetheless vitally important) mechanics of commanding a brigade in action. It gave him an important background for his later commands. As Chief of the General Staff from 1963 to 1966, he set the parameters for the Australian Army's commitment to the Vietnam War. Then, when he became Chairman of the Chiefs of Staff Committee in 1966, he assumed overall responsibility for the commitment to Vietnam, which almost simultaneously grew from a mainly army affair to a tri-service commitment. In all this, the management of relations with allies was a key feature.

Finally, we should note that Wilton's predecessor as commander of the 28th Brigade, Thomas Daly, succeeded Wilton as Chief of the General Staff from 1966 to 1971, and was therefore responsible for maintaining the Australian Army in Vietnam. Frank Hassett, who commanded 3RAR in the Battle of Maryang San in 1951, rose to become the first Chief of the

\footnotetext{
36 Ibid., p. 79.

37 Wilton Diary, Wilton Papers, ADFA Library.

38 'Commonwealth Division in Korea', address by Wilton, undated, Wilton Papers, folder 23, ADFA Library.
} 
Defence Force staff. He was succeeded in that role by Arthur MacDonald, who had commanded 3RAR in 1953. Ron Hughes, who commanded 3RAR in 1951-52, commanded the 1st Australian Task Force in Vietnam and was commander of the 1st Division in the 1970s. The Australian Army's higher command experience in the Korean War therefore influenced the Australian Army, and indeed the Australian Defence Force, for a generation beyond the end of the war. 
This text is taken from In from the Cold: Reflections on Australia's Korean War, edited by John Blaxland, Michael Kelly and Liam Brewin Higgins, published 2020 by ANU Press, The Australian National University, Canberra, Australia. doi.org/10.22459/IFTC.2019.08 